\title{
Mergers and Acquisitions Trends - The Indian Experience
}

\author{
Viral Upendrabhai Pandya ${ }^{1}$ \\ ${ }^{1}$ Asia Pacific International College, 399, Lonsdale Street, Melbourne, VIC 3000, Australia \\ Correspondence: Viral Upendrabhai Pandya, Asia Pacific International College, 399, Lonsdale Street, Melbourne, \\ VIC 3000, Australia.
}

Received: November 29, 2017

Accepted: December 21, 2017

Online Published: January 2, 2018

doi:10.5430/ijba.v9n1p44

URL: https://doi.org/10.5430/ijba.v9n1p44

\begin{abstract}
This paper measures the mergers and acquisitions sector of India from 1991 to 2010 with the help of time-series data along with major recent worldwide developments. The time series analysis makes clear the trend in mergers and acquisitions activity in India and is categorized broadly three ways, namely, the era of consolidation (1991 - 1995), the era of foreign acquisitions $(1995$ - 2002) and the era of venturing abroad (2002 - 2012). It is valuable to take note of the impact of recent changes in the economic, political and social environment of the world in different sectors and sub-sectors of the economy. Mergers and acquisitions is the sector which is highly elastic in its behavior with respect to changes of government policies and political factors. This paper also categorizes trends in manufacturing and non-manufacturing sectors to provide definite evidence for motives and reasons behind the particular behavior observed, and the prospective future of mergers and acquisitions activity in India.
\end{abstract}

Keywords: mergers and acquisitions, trend analysis, merger wave, mergers and acquisitions in India

\section{Introduction}

The Indian economy has witnessed a phenomenal propensity for Mergers \& Acquisitions (M\&A) for the last three decades. M\&A activity has never been as high, with an annual volume (9.7\% of Asia Pacific region) of USD 35.9 billion, with a total 409 deals in 2016 (IMPA Insights, 2016). All big-four Management Consulting groups estimate a record- breaking high level of growth in the M\&A sector in India. A modification in the MRTP Act has played a crucial role in the motivation for M\&A activity as it has shown its potential for raising financial synergy as well as being a prominent and authentic strategy for expansion. The leading sector for mergers and acquisitions for the last four years was the Energy, Mining and Utilities sector in India, followed by telecommunications, consumer durables and pharmaceuticals (IMPA Insights 2016). Merger and acquisition activities have been a prominent not only in capitalist economies but also in emerging economies since the last decade. Results show consistence in the performance of this means of corporate restructuring. The main motive behind mergers and acquisitions is to create synergy; that is, one plus one is more than two, and this rationale attracts companies toward merger activity during times of difficult business conditions (Agrawal Manish 2003). Merger and acquisition activity helps companies to secure the benefits of greater market share and cost efficiency, and these benefits are demonstrated by the superior post-merger performance of the acquiring entities. (Pandya 2012)

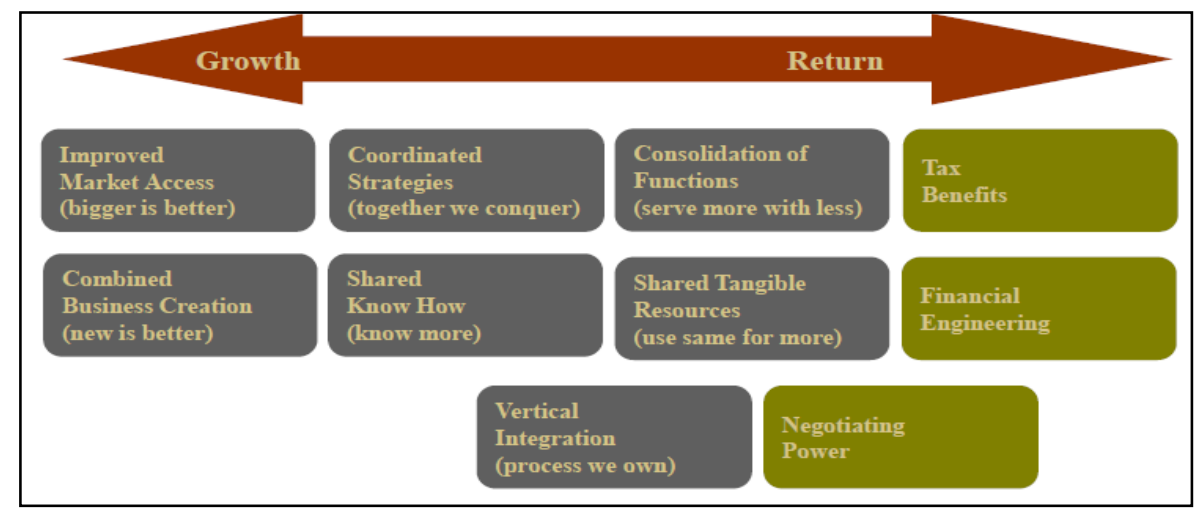

Figure 1. Motives of M\&A

Source: Viral Pandya 2012 
The overall objectives of merger and acquisition activities can be divided into two broad categories, namely, growth and return, and research suggests that overall, major mergers and acquisitions occur in India because of the latter objective (return). The major objective of mergers and acquisitions in India is understood to be the getting of tax benefits and the creation of financial synergy (Mergerstate Report, 2012). Because of this, merger and acquisition activities are considered to be more a financial synergy-generating strategy than a procurement strategy. Another major advantage of mergers and acquisitions is the achievement of inorganic growth of the firm, through which both profit maximization and wealth maximization are achieved by the acquiring organization.

Recent world trends suggests that market leaders prefer fast action for the implementation of an expansion strategy, and merger and acquisition is the preferred option for this. It is also observed from the same trend source that merger and acquisition is the most reliable and favored option for corporate restructuring (Mergerstate 2015). Mergers and acquisitions are the solution to major strategic challenges like economies of scale, economies of scope, vertical and horizontal integration, development of complimentary resources, effective application of surplus funds, and enhancing managerial effectiveness. Thus there is little doubt for the preference of mergers and acquisitions over the remaining options for corporate restructuring or executing an expansion strategy; and most importantly it could be coupled with financial synergy.

Because of these reasons, the last decade has proved to be a haven for merger and acquisition activity across the globe, as most of the drivers of this activity are positive and highly active. Starting with the economic environment for the most of the developing economies, and then the overall political landscape, behavior of capital market, shareholder's activism and confidence in private sector, all are reasons for witnessing phenomenal growth across the world. These are the silent drivers which motivate or indirectly lead merger and acquisition activities in the corporate sector.

\section{Mergers and Acquisitions Global Trends}

The global mergers and acquisitions market demonstrated its flexibility in 2016 with a total volume of USD 3.9 trillion, the third highest performance to this date (M\&A Global Outlook, 2017). Despite a series of political upsets, global merger and acquisition activity (17,369 deals, US\$3.2trillion) reached its third highest deal value since 2007 (US\$3.7trillion), despite value dropping $18.1 \%$ compared to 2015 (18,039 deals, US\$ 4.0tn), with 670 fewer deals announced (Global and regional M\&A: Q1 - Q4 2016). The true picture of merger and acquisition activity can be presented best by a segmented report. Despite challenges, the merger and acquisitions sector demonstrated its strength through its ability to access new regions, products and know-how, economies of scale, and by enhancing productivity through strategic combinations. Cross-border merger and acquisition activity maintained its importance throughout the last two decades and it continued for 2016, accounting for 36\% of total volume versus 31\% in 2015 . China excelled and made a huge contribution to the growth of the merger and acquisition sector as Chinese companies have aggressively sought investment opportunities in the USA and UK (M\&A Global Outlook, 2017).

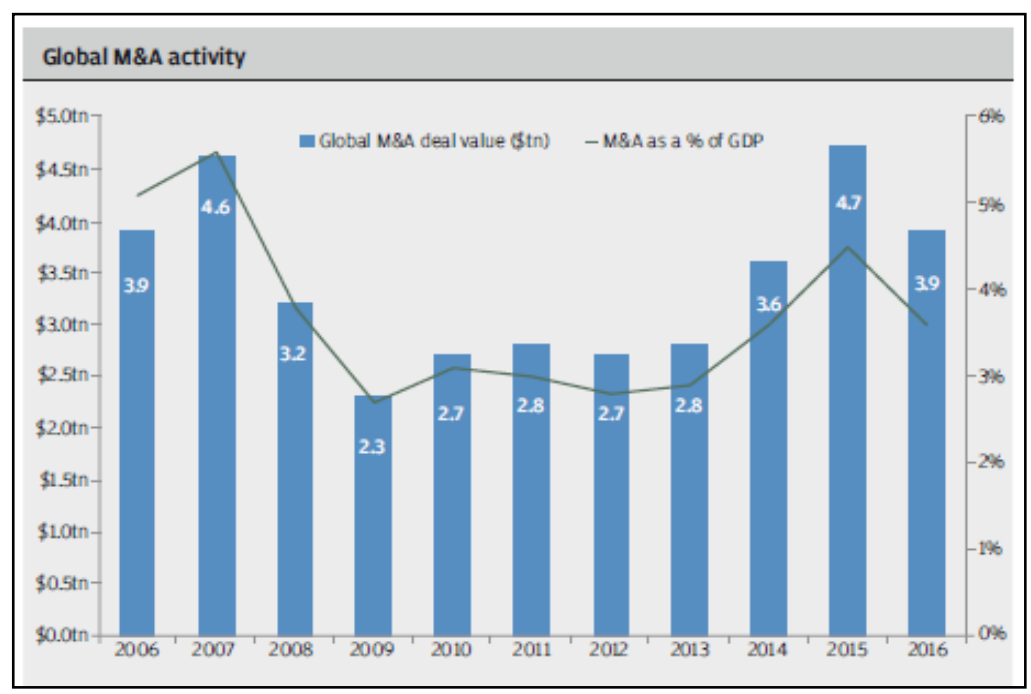

Figure 2. Global M\&A Activity

Source: M\&A Global Outlook, 2017 
Global merger and acquisition activity demonstrated clearly the influence of political and economic factors in the year 2016.

\subsection{Trend in USA}

The USA with its well-developed capital markets offers not only opportunities to identify potential targets by stock prices; it offers as well provision of funds for rapid industry consolidation. Also the USA is a leader setting the global trend in merger and acquisition activity. In the decade of 1990's, however, global competition, deregulation as well as complex and rapidly changing technologies have been the motivations for merger activity. The experience of US in 1980's and 1990's shows that mergers were prevalent in industries experiencing rapid technological change, deregulation, price of stocks or increased foreign competition (Mergerstate 2010). Regulators are looking beyond the competitive effects of mergers (in terms of size of the transaction) to the potential for improving operating efficiency.

Table 1. Trends of M\&As $2000-2009$

\begin{tabular}{lll}
\hline & & Historical merger waves in US \\
$1897-1904$ & First Wave & Horizontal consolidation, Survival of the fittest \\
$1916-1929$ & Second Wave & Increasing Concentration \\
$1965-1969$ & Third Wave & Conglomerate Era \\
$1981-1989$ & Fourth Wave & The Dumping Decade \\
$1990-2009$ & Fifth Wave & The Era of Mega Mergers \\
\hline
\end{tabular}

Source: Mergerstate, Feb. 2010

The first mergers wave started in the US as early as the late 18th century, with the primary focus on survival or horizontal consolidation. Over time this wave developed into mergers and acquisitions being used as the means of increasing market concentration. In the post-world war II period, the USA established as the super-power nation replacing the UK. Accordingly, the era of the conglomerates started in the late 1960s. The fourth wave can be referred as the dumping decade, where the US was most preferred destination for dumping goods and services to rest of the world. The last delineation of a distinct mergers and acquisitions wave can be dated from 1990 to 2009 , where mega-deals were common. The field of mergers and acquisitions is saturated and used for other purposes like tax benefit, corporate restructuring, leverage benefit, cost advantage.

The US leads the world in mergers and acquisitions with a total volume of more than 12,000 completed deals worth just over USD 2,012 billion for the financial year ending March 2017. Despite strong US mergers and acquisitions activity for the past few years, prospects for deal-making are now uncertain, due to major political changes as witnessed during the second half of 2016. The economy expects activity from the major deal-makers - energy, mining \& utilities, and the pharmaceutical industry - to lead growth in US mergers and acquisitions (Global and regional M\&A: Q1 - Q4 2016). 


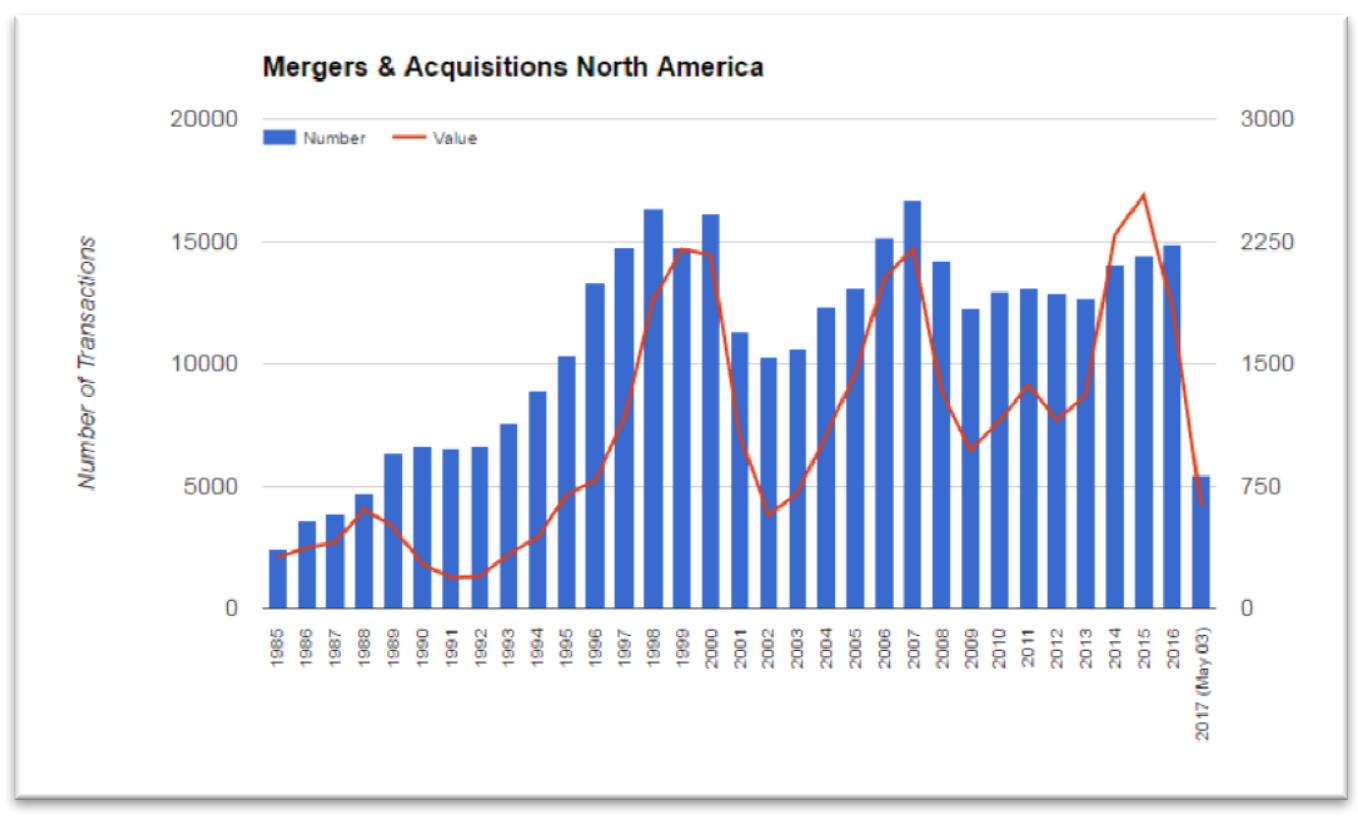

Figure 3. Mergers \& Acquisitions in North America

Source: FACTSET April 2017

The above chart confirms an historical trend for US mergers and acquisitions, with both volume and numbers of deals growing consistently for the last two decades. US deal-making slowed down in 2016, due to change in the political environment and unexpected government policies, but it appears to have settled down in 2017.

\subsection{Trend in Europe}

In 2007, the total contribution of Europe to the global volume of merger and acquisition activity was nearly $40 \%$. For European businesses, access to new geographic markets was considered the most important driver behind their acquisition plans, followed by a desire to build scale.

Merger and acquisition activity slowed in 2016 compared with the previous year, as overall transaction confidence level and the resulting level of cross-border M\&A have not been prominent by economic and politial instability both in UK and Western Europe.

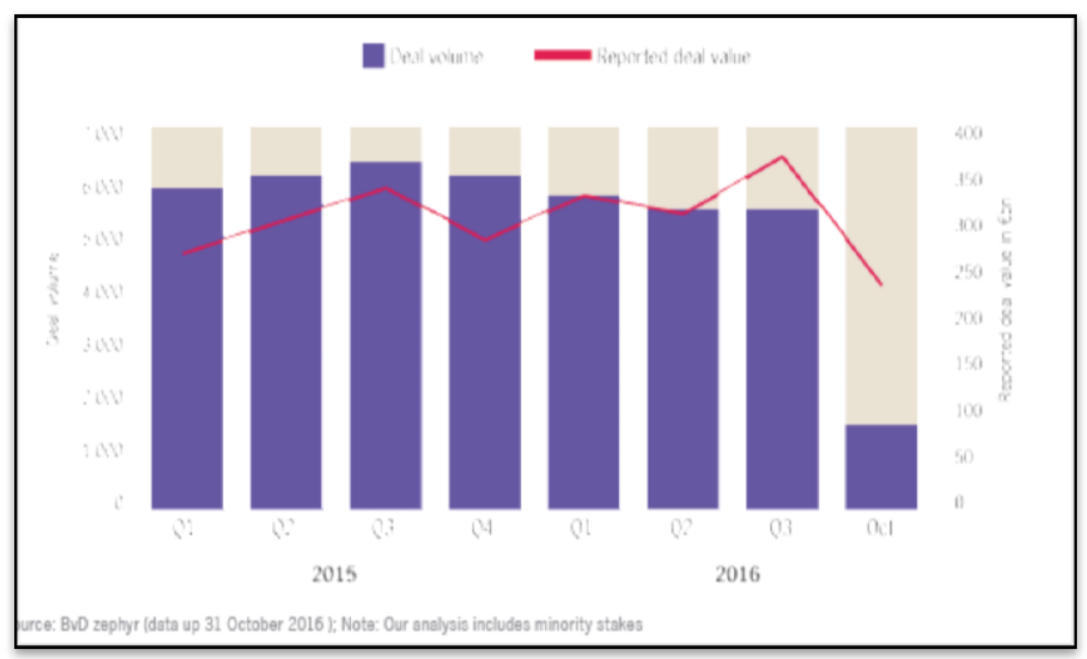

Figure 4. Trends in Europe

Source: Grand Thornton, 2017 
As noted, the impact of political and economic challenges, particularly in the US, slowed merger and acquisition activity, but looking at the first quarter performance in the above figure, it shows resurgence in activity, indicating an adjustment by the corporate world to the changed dynamics. Central and eastern European countries like Poland and Czech Republic have lead activity in this sector in Europe (Grant Thornton, 2017). The volume of merger and acquisition deals in Europe registered a downward move of almost 12\% in first quarter of 2017 compared with 2016, with a total 3,710 deals (FACTSET 2017). It has already been observed that trend of mergers and acquisitions in Europe go hand in hand with the trend in the US. In 2016 technology, media and telecommunications made the largest contribution (21\%) to growth in the sector, with support of the consumer and retail sectors (12\% and 16\% respectively). Growth in the merger and acquisitions sector is like to accelerate in the near future, due to rapid changes in manufacturing technology, production techniques, new product development and market demand (Grand Thornton, 2017).

\subsection{The Trend in India}

According to Forbs, there are major four trends in merger and acquisitions in India, namely, an abundance of liquidity, slowly rising debt costs, energy and technology leading the way, and political factors (mainly in the US) to watch for in 2017 (Forbs, Jan 13, 2017). The major reason behind this is strong government and political support for growth of business, desire to reduce dependence on supply chain uncertainties by backward or forward integration, taxation and distressing sales \& marketing department by horizontal integration. (PWC Report, 2017).

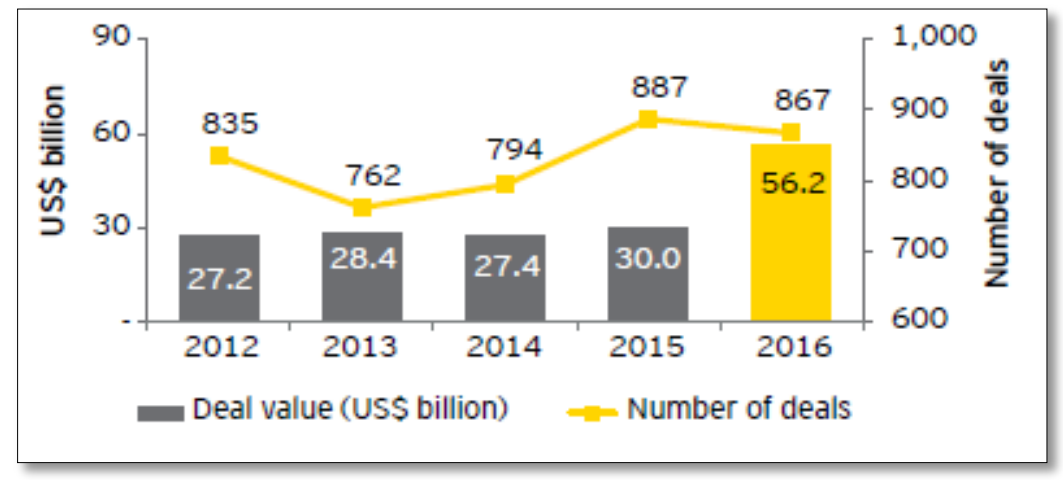

Figure 5. Recent M\&A Activity in India

Source: Earnest \& Young, Transactions 2017

2016 was an encouraging year for the merger and acquisitions sector in India, due to stability of government policy and the capital market. This stability resulted in a record volume - USD 56.2 billion - the highest since 2010. As has been noted 2016 was a year when the US and Western Europe experienced a considerable set back due to government and political instability.

This performance depends largely on government policy. Domestic activity dominates the Indian mergers and acquisitions sector, with USD 25.1 billion total volume and 505 deals in 2016. This is a 5\% growth in comparison with 2015. The leading contributors to merger and acquisition activity in India were oil and gas, financial services, cement and building products, followed by pharmaceuticals and infrastructure (Ernest \& Young, 2017). The major reasons for the advent of these mergers were market share expansion, reduction of debt, and taxation advantage (i.e. generating financial synergy). 


\begin{tabular}{|l|c|c|c|c|}
\hline \multirow{2}{*}{} & \multicolumn{2}{c|}{2015} & \multicolumn{2}{c|}{2016} \\
\cline { 2 - 5 } & Count & $\begin{array}{c}\text { Value (USS } \\
\text { million) }\end{array}$ & Count & $\begin{array}{c}\text { Value (USS } \\
\text { million) }\end{array}$ \\
\hline Domestic & 483 & 16,360 & 505 & 25,141 \\
\hline Inbound & 258 & 9,949 & 204 & 21,396 \\
\hline Outbound & 146 & 3,708 & 158 & 9,650 \\
\hline Total & $\mathbf{8 8 7}$ & $\mathbf{3 0 , 0 1 7}$ & $\mathbf{8 6 7}$ & $\mathbf{5 6 , 1 8 7}$ \\
\hline
\end{tabular}

Figure 6. M\&A recent behavior in India

Source: Earnest \& Young, Transactions 2017

In recent years, the mergers and acquisitions sector in India has looked strong and consistent, against all odds in international market. The major reason behind the outstanding performance of the experience in India is the strength of the domestic economy and the desire to grow at the international level. The year 2016 witnessed 362 cross border deals with a total volume of USD 31.1 billion. The US gave strong support for cross-border mergers and acquisitions.

\section{Objectives and Research Methodology}

The objective of this research paper is to analyse the trend of mergers and acquisitions in India for the recent period. The methodology adopted is the observational research based on the metadata for mergers and acquisitions.

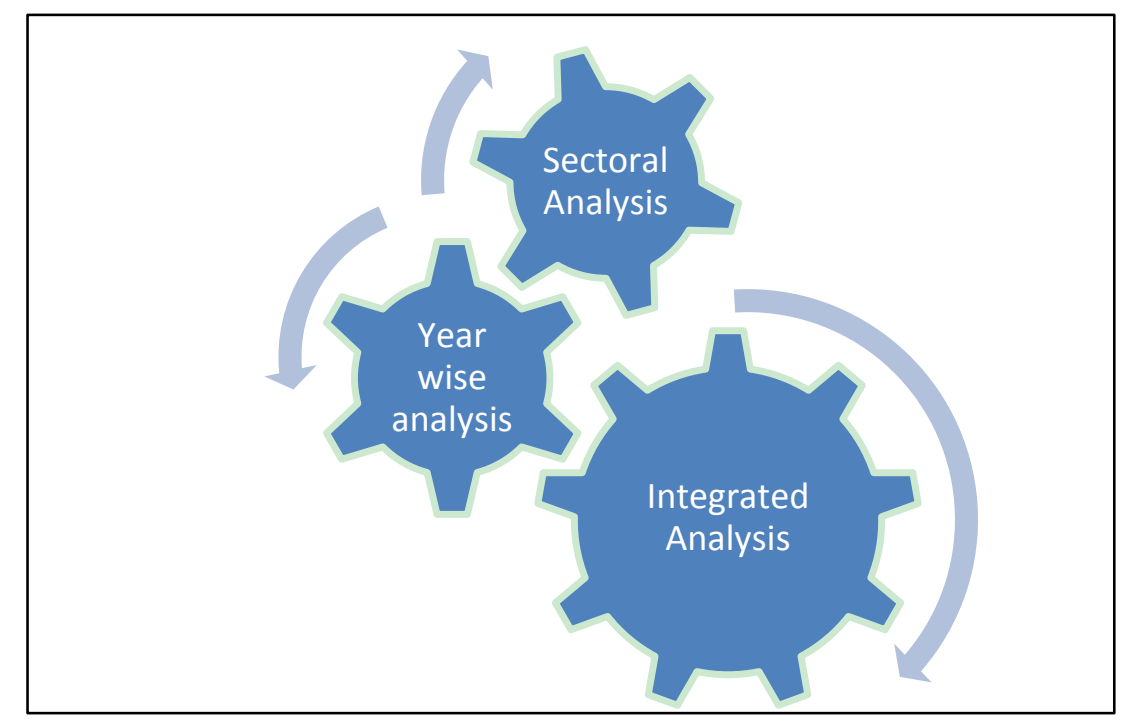

Figure 7. Trend analysis objectives

The trend analysis was steered in two major ways:

- Year-wise analysis

- Sector-wise analysis

Further, the analysis was segregated into the manufacturing sector and the non-manufacturing sector. Furthermore micro level classification for trend analysis was achieved in terms of mean of payment, cross border vs. domestic. But primarily it can be divided into two ways i.e. year wise as and sector wise analysis of trends of mergers and acquisitions. The overall trend analysis can be presented from the above figure. Time-series data, 1991 - 2010, was used. 


\section{Literature Review}

Merger of two weak banks or the merger of one 'healthy' bank with one weak bank may be seen as a rapid way to first, improve profitability, and then second, to spurr internal growth (Franz, H. Khan 2007). Beena (2004) presents a trend analysis for mergers and acquisitions in India, for the period 1990 to 2000. Her analysis is in the form of manufacturing and non-manufacturing organisations in the range of five years. She also presents trend analysis in terms of a segregation of domestic and foreign organisations. Finally she reports integrated analysis for foreign and domestic, and manufacturing and non-manufacturing, firms. The evidence, based on crisis-hit countries, showed that TNCs had acquired local firms that were competing with them in the same market prior to the acquisition (Zhan \& Ozawa 2001). The anti-trust law of the 1920s was stricter than it was during the period of the first merger wave. Operating within a stricter environment, the second merger wave created fewer monopolies, but more oligopolies and much vertical integration (Gaughan, 1996).

Andrews (1951) further argued that general management skills contributed to diversification, helping to create "successful diversification - because it always means successful surmounting of formidable administrative problems - develops know-how which further diversification will capitalize and extend."

Participation of foreign controlled firms in the mergers and acquisitions process has increased significantly during the second half of the nineties. According to Saha (2001), around 38 per cent of the total Foreign Direct Investment (FDI) made by multinational corporations (MNCs) during 1991-1998 was financed through cross-border mergers and acquisitions activity, either through acquisition of substantial equity stakes in existing ventures or through buy-out of real assets through asset-sales.

Mergers are commonly referred to as either 'merger by absorption' or 'merger by establishment' (Chunlai Chen and Findlay, 2003, Nakamura, 2005). Merger by absorption is the situation in which one company buys all the stocks of one or more companies (i.e., absorbs) and the absorbed companies cease to exist, whereas merger by establishment refers to the situation where two or more firms are merged into a newly-created single firm and the combining firms in the merger are dissolved (Chunlai Chen and Findlay, 2003). According to Nakamura (2005), merger by absorption could be considered as a de facto acquisition. Besides, the term 'consolidation' could be used to imply a merger by establishment (Gaughan, 2002).

The developed countries of the European Union (EU15) and the United States, have been the largest acquirer and target countries for mergers and acquisitions. For the 2003 - 2005 period, developed countries accounted for $85 \%$ of the USD 465 billion cross-border M\&As, $47 \%$ and 23\% of which respectively pertain EU15 and US firms either as acquirer or as target countries (UNCTAD (2006)).

\section{Analysis}

Mergers and acquisitions (M\&As) have been a part of the process of industrial growth in the advanced capitalist countries since the last few decades. But in India it has become a regular phenomenon. The striking feature of the present wave of M\&As that picked up since the introduction of economic system is that it includes many cross-border (CB) deals and is propelled by a different set of forces. The total number of M\&As worldwide increased almost three-fold during 1990 to 1999 while their total value has increased by five-fold during the corresponding period. For the period $2000-2009$, the total number of M\&As increased fivefold, which increase led to an almost nine-fold increase in total value. In India, the global environment that emerged after new policy regime of 1991, i.e. privatisation, trade liberalisation, finance and investment, as well as technological change has created an environment conducive to Cross Border Mergers (UNCTAD 2000). Mergers of firms belonging to the same business groups operating in similar product-lines appeared to dominate the Merger-wave in India. The participation of foreign-controlled firms in the mergers and acquisitions process has increased significantly during the second half of the nineties. Around 37.7 per cent of the total Foreign Direct Investment (FDI) made by multinational corporations (MNCs) during 1991-1998 was financed through cross-border M\&As activity, which increased to around 50\% during 2000-2009.

\subsection{M\&A Trend Analysis for India}

Substantial growth of M\&As in the Indian corporate sector has been witnessed since the 1990s. For instance total number of M\&A has increased to 2701(source: capital line) during 2000-2009 (Table 1) from 1034 during 1990-1999(Table 2) and 268 during 1980-1990s. Manufacturing sector accounts for 78\% of the M\&A in India. 
Table 2. Trends of M\&As during 2000-2009

\begin{tabular}{cccc}
\hline Year & Non-Mfg & Mfg & Total \\
\hline $2000-2004$ & $21.6 \%(58)$ & $78.4 \%(210)$ & 268 \\
$2005-2009$ & $22.2 \%(531)$ & $77.8 \%(1857)$ & 2388 \\
$2000-2009$ & $22.2 \%(589)$ & $77.8 \%(2067)$ & 2656 \\
\hline
\end{tabular}

Table 3. Trends of M\&As during 1990 to 2000

\begin{tabular}{cccc}
\hline Year & Non-Mfg & Mfg & Total \\
\hline $1990-95$ & $39.9 \%(116)$ & $60.1 \%(175)$ & 291 \\
$1995-00$ & $31.4 \%(233)$ & $68.6 \%(510)$ & 743 \\
$1990-00$ & $33.7 \%(349)$ & $66.3 \%(685)$ & 1034 \\
\hline
\end{tabular}

While the Indian corporate houses seem to have been preparing to face foreign competition during the first phase (1990-2000), the second phase (2000-2009) witnessed a large presence of multinational firms. MNCs have actively participated in the M\&A process in order to gain market entry or to strengthen their presence. The analysis revealed that during 2000 - 2009, most of M\&As were in finance, real estate, pharma, capital goods, IT, textiles, hotels \& restaurants, consumer durables, alcoholic industries. On the basis of year-wise analysis, in 2006 the number of M\&As were highest during 2000-2009. In 2006, 927 M\&As were completed, in 2007 and 2005 there were 517 and 427 respectively.

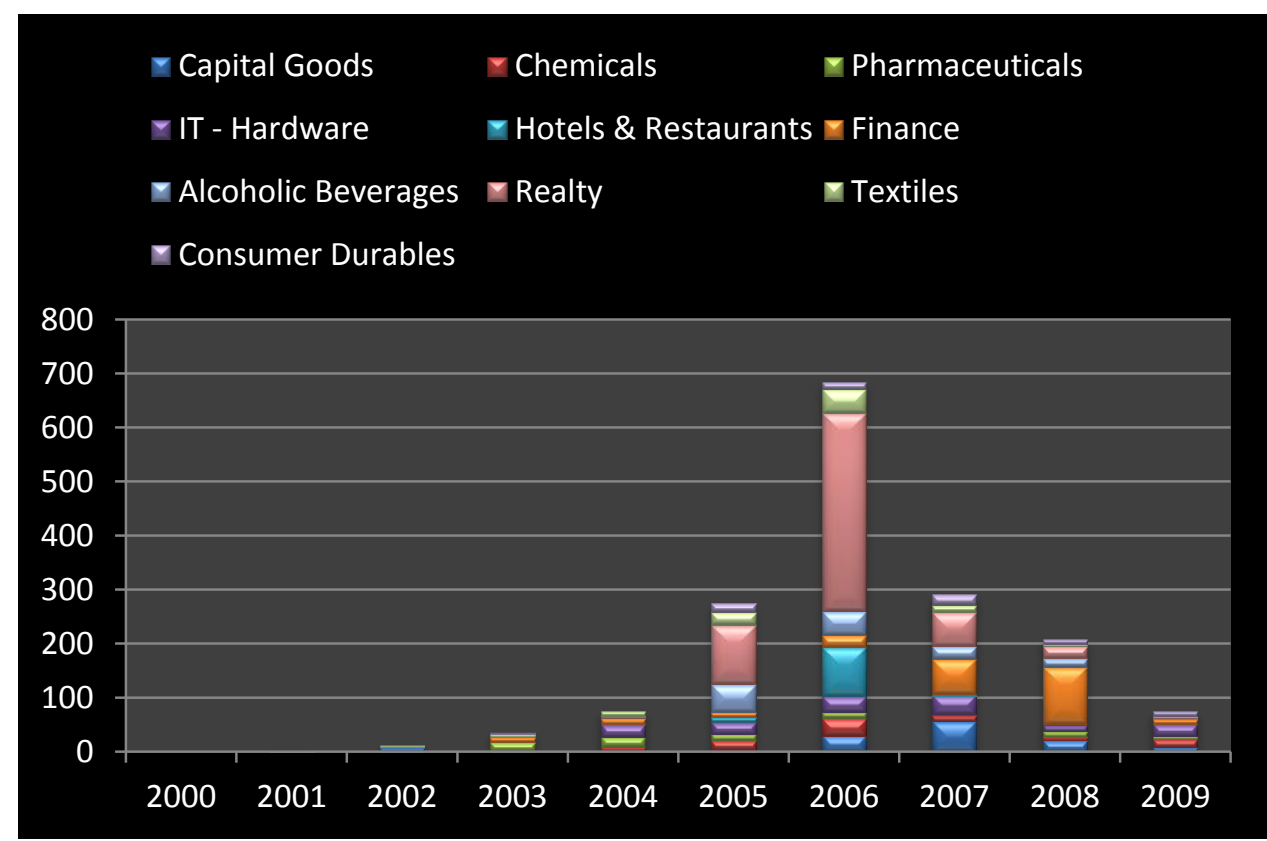

Figure 8. Year wise analysis 


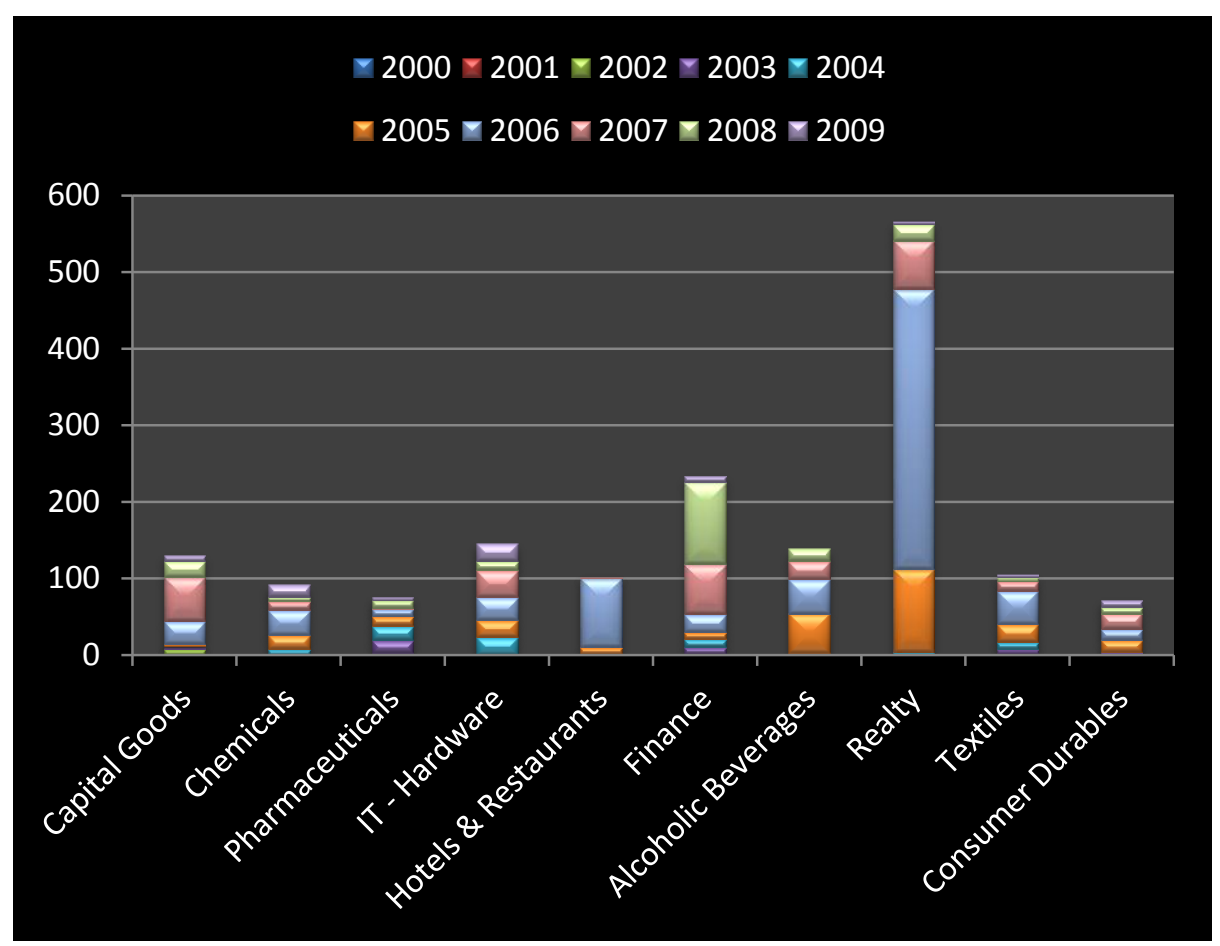

Figure 9. Sector wise Analysis

The trend of mergers and acquisitions is clear from above two charts. It shows continuous growth and improvement. The years 2006 and 2007 were crucial for mergers and acquisitions in India. With overall boom in the market, the M\&A were also high in that two years. The chart 1 and chart 2 show that the real estate sector and the financial sector were the main attractions for acquisitions in India.

In terms of periodic analysis, the first phrase i.e. before 1990 - 95 may be named the era of consolidation where major players of the domestic company started with multinational players who were attracted by the liberalization policy and economic reforms in India. The second phrase may be called the era of foreign acquisitions when international players started seeking Indian companies to enter the Indian market. The last phase i.e. post year 2002 can be considered as venturing abroad as Indian companies engaged in major foreign acquisitions in the industrialist countries and placed India on the global map of industrial growth.

\section{Findings \& Conclusion}

There was significant growth of mergers and acquisitions in India post the 1990s. Between 1980 and 1990 the total number of mergers and acquisitions was 268 , and this number increased substantially to 1,034 during the subsequent decade 1990 - 2000, with a further substantial increase for the decade $2000-2009$ to 2,656. This upward trend supports the analysis as the M\&A activity is growing at more than $100 \%$ growth rate. The role of the non-manufacturing sector in M\&A activity decreased. For the decade $2000-2010$, more than $77 \%$ of merger and acquisitions activity belonged to the manufacturing. It was around $65 \%$ in the previous decade i.e. 1990 to 2010 . The data is surprising as the financial services sector grew at more than $80 \%$ over this period. The major contribution was from the reality sector as the sector has performed more than 566 mergers in last decades???vague. Mergers and acquisitions activity peaked in the year 2006.

In terms of periodic analysis, the first phase i.e. before 1990 - 95 may be named as era of consolidation where major players of domestic company started with multinational players who were attracted by the liberalization policy and economic reforms in India. 
Table 4. Merger Waves in India

\begin{tabular}{lll}
\hline Wave & Period & Name \\
\hline First Wave & $1991-1995$ & Era of Consolidation \\
Second Wave & $1995-2002$ & Foreign Acquisitions \\
Third Wave & $2002-2009$ & Venturing Abroad \\
\hline
\end{tabular}

The second phrase may be called as era of foreign acquisitions when international players started seeking Indian companies to enter in Indian market. The last phrase i.e. post year 2002 can be considered as venturing abroad as Indian companies have done major foreign acquisitions and placed India at global map of industrial growth. After the year 2002, there was a considerable number of foreign acquisitions performed by Indian companies as the market was in booming stage and significant increase in the value of shares of top companies was experienced which leads to increase their financial strength and plan for foreign acquisitions.

Mergers of firms belonging to the same business groups operating in similar product-lines appeared to dominate till 2000 but since then companies have increased the M\&A activity for diversification. That means, M\&A is used not only as mean for corporate restructuring but also as an effective means of expansion and entry to new markets.

\section{References}

Agarwal Manish. (2003). Analyses of Mergers in India, Unpublished MPhil Dissertation submitted to the University of Delhi. Delhi School of Economics.

Ansoff, H.I., \& Weston, J.F. (1962). Merger Objectives and Organisational Structure. The Quarterly Review of Economics and Business, 2(3), 49.

Aspinwall, L. (1991). The effect of upword and downword social comparasions on affect, self ev.

ASSOCHEM Report, June 2012.

Bahde, K. (2003). Boundry spanners: A rational, social constructionist perspective. Paper presented at the acadamy management meeting, Seattle, Washington.

Bahde, K. (2002). Boundary spanning merger \& acquisitions integration managers. Paper Presented at the M\&A summit.

Barney, J. (1991). Firm resources and sustained compititive advantage. Journal of Management, 17(1), 99-120. https://doi.org/10.1177/014920639101700108

Basant, R. (2000). Corporate Response to Economic Reforms. Economic and Political Weekly, XXXV(10).

Beena, P.L. (2000). An Analysis of Mergers in the Private Corporate Sector in India. Working Paper 301, Centre for Development Studies, Trivandrum.

Beena, P. (2000). An analysis of Mergers in the Private corporate sector in India. working paper 301, Center for development Studies, Trivandrum.

Beena. (2004). Towards Understanding the manager wawe in Indian corporate sector: comparative perspective. Working paper 355.

Berger, P. (1967). The social construction of reality: a treatise in the sociology of knowledge. New York.

Bettis, R. (1995). The dominent logic: Reteispective and extension. Stratagic Manageent Journal, 16(1), 5-14. Aluation and expactations of future sucess. Los Angles: University of California.

Bhaumik, S, Beena, P.L, Bhandari, L., \& Gokarn, S. (2002). Survey of FDI in India. DRC Working Paper No.6, London Business School, UK.

BSE Sensex information, July 2012.

Capital line database, 2012.

Centre for Monitoring Indian Economy, "PROWESS Computerised Data Base", CMIE, Mumbai.

Conger, J. (1988). The empowerment process: Integrating theory and practice. Academy of Management Review, 
$13(3), 471-482$.

Coolins, J. (1994). Built to last: Successful habits of visionary companies. New York: Harper Business.

Feldmen, M. (2002). Organizational routines as sources of connections and understandings. Journal of Management Studies, 39(3), 309-331. https://doi.org/10.1111/1467-6486.00294

Fletcher, J. (1995). Radically transforming work for the 21st century: A feminist reconstruction of "real" work. Academy of Management Journal Best Papers Proceedings, $448-452$. https://doi.org/10.5465/AMBPP.1995.17536733

Fletcher, J. Disappearing acts: Gender, power and relational practice at work. Cambridge: MIT press.

Forbs India, Economic Report, 2017.

Gaughan. (1996). Macro-economic impact of merger, acquisitions and consolidations. Economic Review.

Grand Thornton, IBR, 2009, 2011, 2012 \& 2017.

Journal for Mergers \& Acquisitions, HBR, 2008.

Merger Market Report: Global and regional M\&A: Q1 - Q4 2016.

Mergerstate Report for the year 2009, 2010 \& 2011.

Saha, Biswatosh. (2001). Investment Policy in India. Paper presented in a seminar, organised by CUTS Centre for International Trade, Economics and Environment, Jaipur.

Schachter, S. (1964). The interaction of cognitive and physiological determinants of emotional state. In L. Berkowitz (Ed.), Advances in Experimental Social Psychology (Vol. 1). New York: Academic Press. https://doi.org/10.1016/S0065-2601(08)60048-9

Schmalensee, R. (1987). Horizontal Merger Policy: Problems and Changes. Journal of Economic Perspectives, 7(2), 41-54. https://doi.org/10.1257/jep.1.2.41

Thomson Secuity data, $2009 \& 2017$.

UNCTAD. (1997). Transnational Corporations, Market structure and Competition Policy. World Investment Report, Geneva.

UNCTAD. (1999). Foreign Direct Investment and the Challenge of Development. World Investment Report, Geneva.

UNCTAD. (2000). Cross-border Mergers and Acquisitions and Development. World Investment Report, Geneva.

Wittgenstein, L. (2001). Philosophical investigations (3rd ed.). Oxford: Blackwell.

www.forbs.com, Jan. 13, 2017 11:28 am.

Wylie, I. (2003). Can Philips learn to walk the talk?. First Company.

Zhan James, \& Terutamo Ozawa. (2001). Business Restructuring Asia: Cross-Border M\&As in the Crisis Period. Copenhagen Business School Press, Denmark. 